\title{
Modifikasi Autoclave Berbasis Atmega328 (Suhu)
}

\author{
Tri Hardono*1, Kuat Supriyadi ${ }^{2}$ \\ Universitas Muhammadiyah Yogyakarta, Indonesia
}

INFO ARTIKEL

Alamat Web Artikel:

https://journal.umy.ac.id/index.php/mt /article/view/7393

DOI:

https://doi.org/10.18196/mt.010210

\section{Data Artikel:}

Diterima:

04 April 2020

Direview:

15 April 2020

Direvisi :

21 April 2020

Disetujui :

30 April 2020

Korespondensi:

tri.hardono.2016@vokasi.umy.ac.id

\begin{abstract}
ABSTRAK
Autoclave merupakan alat pemanas tertutup yang digunakan untuk mensterilisasi suatu instrumen bedah menggunakan uap dengan suhu $121^{\circ} \mathrm{C}$ dan tekanan 1,1 bar selama kurang lebih 15 menit. Perancangan alat ini menggunakan mikrokontroler ATMega 328 yang digunakan sebagai pengendali utama, driver heater untuk menyalakan heater sehingga terjadi proses pemanasan. Sensor suhu dan tekanan melakukan pembacaan suhu $121{ }^{\circ} \mathrm{C}$ dengan tekanan 1,1 bar yang akan tertampil pada LCD. Alat autoclave ini dilengkapi dengan sistem pembuangan uap secara otomatis, dapat melakukan pembuangan uap jika driver solenoid valve mendapatkan tegangan dari mikrokontroler. Pengujian pada alat ini akan dibandingkan dengan alat untuk pengukur suhu yaitu thermometer suhu, pengukuran timer dibandingkan dengan stopwatch dan dilakukan uji sterilisasi menggunakan tape autoclave. Pada pengukuran suhu didapatkan nilai koreksi sebesar 0,5 lalu pada pengukuran timer 900 detik didapatkan nilai koreksi sebesar 3,3 sedanglan untuk uji coba sterilisasi didapat waktu sterilisasi efektif dengan waktu 15 sd 20 menit. Dari pengukuran dan pengujian sterilisasi dapat disimpulkan bahwa pengukuran memiliki nilai koreksi yang tidak jauh dan alat modifikasi autoclave ini dapat melakukan dapat melakukan proses sterilisasi dengan waktu efektif selama 15 menit.
\end{abstract}

Kata Kunci: Autoclave, Kontrol Suhu, Kontrol Tekanan, Pembuangan Uap Otomatis

\section{PENDAHULUAN}

Seiring dengan berkembangnya teknologi kesehatan di Indonesia semakin meningkatnya kebutuhan akan instrumen medis. Instrumen medis sangat bepengaruh sebagai penunjang untuk penyembuhan luka atau penyakit terhadap kesembuhan pasien. Malpraktek pada dunia kedokteran banyak terjadi akibat faktor teknis dalam masa penyembuhan. Salah satu faktor teknis penyebab terjadinya malpraktek adalah kontaminasi terhadap alat yang digunakan dalam dunia kesehatan. Salah satu cara untuk mencegah terjadinya kontaminasi pada peralatan medis yaitu dengan melakukan sterilisasi [1]. Instrumen kesehatan steril memberikan peran penting dalam mengurangi penyebaran penyakit infeksi dalam tindakan pelayanan kesehatan [2]. Mikroorganisme sering menjadi penyebab terjadinya kontaminasi karena menempel pada peralatan yang digunakan untuk pengobatan dan tidak kasat mata. Salah satu cara untuk mencegah terjadinya kontaminasi pada peralatan medis yaitu dengan melakukan sterilisasi. Sterilisasi biasanya dilakukan pada intrumen pakai ulang seperti gunting, pisau bedah dan pinset [1].

Sterilisasi dapat didefinisikan sebagai proses yang secara efektif membunuh atau menghilangkan mikroorganisme yang dapat berpindah (seperti jamur, bakteri, virus) dari permukaan peralatan [3]. Mikroorganisme dapat dikendalikan yaitu dihambat atau dimatikan dengan menggunakan berbagai proses. Metode sterilisasi dapat dibagi menjadi dua kelompok umum yaitu fisik dan kimia meskipun sterilisasi dapat dicapai dengan bahan kimia tertentu, umumnya metode fisik lebih handal. Salah satu metode paling efektif untuk mematikan mikroorganisme menggunakan suhu tinggi [4]. Salah satu alat sterilisator yang menggunakan metode panas uap bertekanan adalah autoclave [5]. Autoclave adalah alat untuk mensterilkan berbagai macam peralatan dan perlengkapan yang digunakan dalam mikrobiologi menggunakan 


\section{Hardono, Supriyadi}

Modifikasi Autoclave Berbasis Atmega328 (Suhu)

uap air panas pada umumnya 15 Psi dan dengan suhu $121^{\circ} \mathrm{C}$. Lama sterilisasi yang dilakukan selama 15 menit [6].

Penelitian dari sebelumnya dilakukan oleh Moch Fauzi A yang berjudul Modifikasi Autoclave Berbasis Mikrokontroller AT89s51. Penelitian dan pembuatan model alat ini menggunakan metode eksperimental yaitu memodifikasi alat Autoclave Berbasis Mikrokontroller. Penelitian ini bertujuan untuk mempermudah perawat dan dokter dalam pengoperasian alat Autoclave. Sistem yang digunakan adalah mikrokontroller AT89s51. Penelitian ini masih menggunakan sensor suhu LM35, kekurangannya adalah sulitnya membuat chasing untuk sensor tersebut dikarenakan untuk ketahanan panas yang tinggi sensor suhu LM35 rendah [7].

Berdasarkan permasalahan diatas, maka akan dirancang sebuah alat yaitu Modifikasi Autoclave berbasis ATMega 328 (suhu) dengan tampilan suhu dan tekanan secara digital agar dapat memudahkan user untuk melihat dan memastikan suhu dan tekanan tercapai pada autoclave tersebut. Serta pembuangan uap secara otomatis menggunakan Solenoid Valve.

\section{METODE PENELITIAN}

Metode yang dilakukan pada penelitian ini, terdiri dari : Perancangan Hardware, Perancangan Software, dan Pengambilan data.

\subsection{Perancangan Software}

Berdasarkan diagram alir pada Gambar 1, sebelum proses berlangsung, mikrokontroler akan melakukan inisialisasi LCD (Liquid Crystal Display). Setelah itu ditekan tombol start, maka driver heater akan bekerja yang akan menghidupkan heater yang di-supply dari tegangan 220 VAC. Kemudian sensor suhu mulai bekerja membaca suhu yang berada didalam chamber. Apabila suhu didalam chamber sesuai dengan suhu yang telah di-setting maka proses sterilisasi dimulai dan timer akan aktif sesuai dengan setting waktu yang telah ditentukan. Apabila timer tercapai proses sterilisasi selesai, heater akan berhenti bekerja dan buzzer berbunyi dan proses selesai.



Gambar 1. Diagram Alir 


\section{Hardono, Supriyadi}

Modifikasi Autoclave Berbasis Atmega328 (Suhu)

\subsection{Perancangan Hardware}

Pada perancangan hardware ini, hal yang dilakukan yaitu, perancangan blok rangkaian yang terdiri dari : rangkaian minimum system ATMega 328p dan rangkaian driver.

\subsubsection{Rangkaian Minimum System}

Komponen yang digunakan pada rangkaian minimum system ATMega 328p yang ditunjukkan pada Gambar 2 terdiri dari:

1. Menggunakan IC ATMega 328p.

2. Menggunakan Crystal $16 \mathrm{MHz}$.

3. Tegangan kerja yang digunakan sebesar $+5 \mathrm{~V}$, dan GND.

4. Terdapat push button sebagai tombol reset, resistor 10k, 330 resistor, LED, kapasitor senilai $10 \mathrm{uF}$ dan kapasitor $22 \mathrm{pF}$.

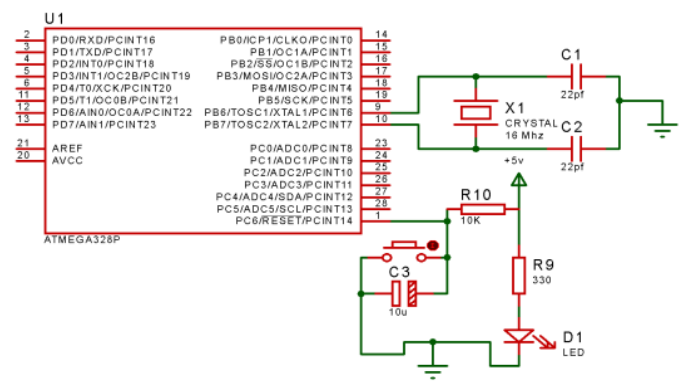

Gambar 2. Rangkaian Minimum System

Untuk mengaktifkan mikrokontroler ATmega 328p maka perlu diberikan tegangan catu daya +5 V DC pada pin 20 dan pemberian tegangan nol (ground) pada pin 22. Disamping itu diperlukan juga pengaktifan osilator internal yang terdapat pada mikrokontroler. Untuk mengaktifkan osilator internal tersebut dalam perancangan ini digunakan kristal $16 \mathrm{MHz}$ untuk memperoleh kecepatan pelaksanaan instruksi per siklus sebesar $16 \mathrm{MHz}$.

\subsubsection{Rangkaian Driver Heater}

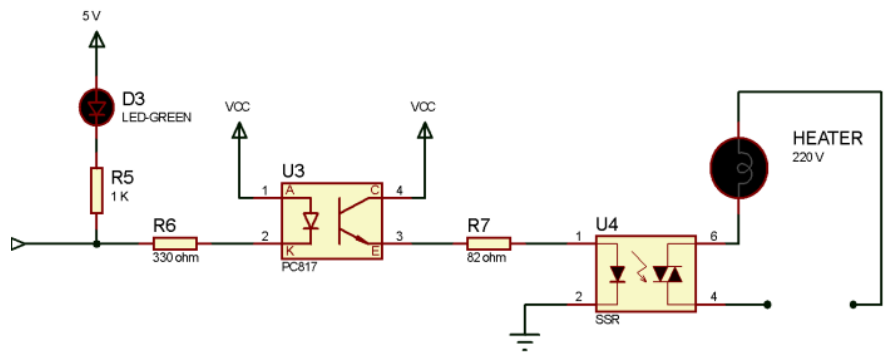

Gambar 3. Rangkaian Driver heater

Prinsip kerja dari driver heater menggunakan SSR pada Gambar 3 sebagai saklar untuk memutus dan menyambung tegangan $220 \mathrm{~V}$ AC yang akan di-supply ke heater. Selain menggunakan SSR, pada rangkaian driver ini juga menggunakan optoisolator yang berfungsi untuk memutus dan menyambung tegangan $5 \mathrm{~V}$ yang akan diloloskan ke SSR, sehingga SSR bekerja bergantung pada optoisolator. Ketika kaki Anoda LED pada optoisolator mendapatkan tegangan $5 \mathrm{~V}$ dan ground dari kaki PD 13 mikrokontroller maka LED pada optoisolator menyala, jika kaki basis phototransistor terkena cahaya akan menyebabkan phototransistor

Medika Teknika : Jurnal Teknik Elektromedik Indonesia, Vol 01 No. 2, April 2020 |61 


\section{Hardono, Supriyadi \\ Modifikasi Autoclave Berbasis Atmega328 (Suhu)}

aktif yang akan meloloskan tegangan $5 \mathrm{~V}$ dari kaki kolektor ke emitor pada opto isolator yang kemudian diteruskan ke SSR sehingga SSR bekerja. Dengan bekerjanya SSR, tegangan 220VAC akan diloloskan ke heater dan heater bekerja.

\subsubsection{Rangkaian Driver Sensor Suhu PT100}

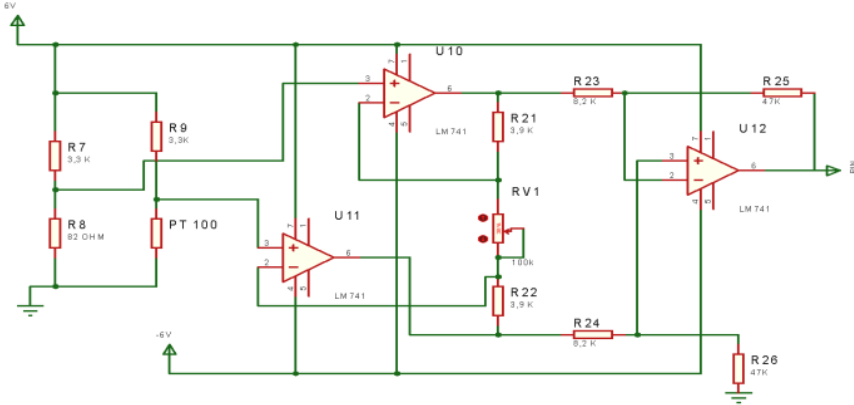

Gambar 4. Rangkaian Driver Sensor Suhu PT100

Prinsip kerja dari rangkaian pada Gambar 4 yaitu output dari sensor suhu PT 100 akan dikuatkan pada rangkaian penguat instrumentasi amplifier yang terdiri dari dua penguat penyangga yang digunakan untuk mempertahankan resistansi kemudian pada rangkaian

penguat diferensial digunakan untuk menguatkan selisih dari hasil kedua rangkaian penyangga. Output dari rangkaian diferensial masuk ke mikrokontroller.

\subsection{Teknik Pengambilan Data}

Pengambilan data dilakukan yaitu dengan melakukan pengukuran suhu $121^{\circ} \mathrm{C}$ menggunakan thermometer suhu sebagai pembanding, pengukuran timer menggunakan stopwatch sebagai pembanding, dan pengujian sterilisasi pada peralatan kesehatan. Pengambilan data yang dilakukan sebanyak 10 kali.

\subsection{Desain Alat}

Pada Gambar 5 merupakan desain modul penelitian.

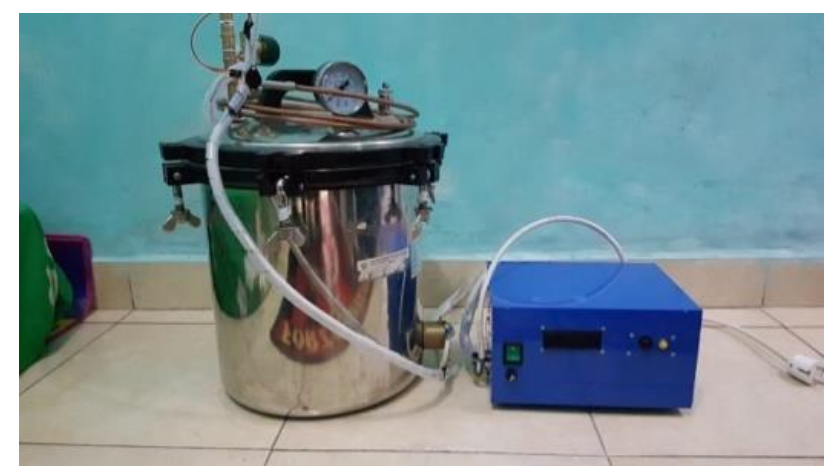

Gambar 5. Desain Modul Alat

Pada modul alat ini memiliki tombol power on/off yang digunakan untuk menyalakan dan mematikan alat. Alat ini memiliki 2 push button sebagai tombol start dan reset. Tombol Start digunakan untuk menjalankan proses Sterilisasi, dan tombol reset digunakan untuk mengulang sistem kembali ke awal, dan memiliki LCD sebagai penampil alat untuk menampilkan nilai tekanan, suhu, dan timer. 


\section{Hardono, Supriyadi}

Modifikasi Autoclave Berbasis Atmega328 (Suhu)

\section{HASIL DAN PEMBAHASAN}

Hasil penelitian dilakukan dengan beberapa pengujian dan pengukuran meliputi :

\subsection{Pengukuran pada suhu $121^{\circ} \mathrm{C}$}

Pengukuran suhu sebesar $121^{\circ} \mathrm{C}$ menggunakan termometer, pengukuran dilakukan sebanyak 10 kali, didapatkan hasil sebagai berikut :

Tabel 1. Pengukuran Suhu $121^{\circ} \mathrm{C}$

\begin{tabular}{|c|c|c|}
\hline No & Hasil Pembacaan Pada Alat & $\begin{array}{c}\text { Hasil Pembacaan } \\
\text { Pada Termometer }\end{array}$ \\
\hline 1 & 121.3 & 121.1 \\
\hline 2 & 121.3 & 121.3 \\
\hline 3 & 121.3 & 121.1 \\
\hline 4 & 121.5 & 121.3 \\
\hline 5 & 121.3 & 121.4 \\
\hline 6 & 121.3 & 121.3 \\
\hline 7 & 121.3 & 121.3 \\
\hline 8 & 121.5 & 121.3 \\
\hline 9 & 121.3 & 121.1 \\
\hline 10 & 121.3 & 121.3 \\
\hline \multicolumn{2}{|c|}{ Rata-rata $\left({ }^{0} \mathrm{C}\right)$} & $\mathbf{1 2 1 . 3 4}$ \\
\hline Simpangan & $\mathbf{0 . 1 4}$ \\
\hline \multicolumn{2}{|c|}{ Eror } \\
\hline
\end{tabular}

Tabel 1 menunjukkan pengukuran suhu pada modul sebesar $121^{\circ} \mathrm{C}$ didapatkan suhu rata-rata sebesar $121,34{ }^{\circ} \mathrm{C}$ dengan koreksi sebesar 0,14 dan nilai error sebesar $0,115 \%$. Setelah dilakukan pengambilan data penempatan sensor yang sama didapat hasil pembacaan yang hampir sama dikarenakan penempatan sensor yang presisi akan mempengaruhi pembacaan suhu didalam chamber.

\subsection{Pengukuran Timer}

Pengukuran timer 15 menit telah dilakukan sebanyak 10 kali dengan membandingkan timer pada alat dengan stopwatch.

Tabel 2. Pengukuran Timer 15 Menit

\begin{tabular}{|c|c|}
\hline Pengukuran Ke- & Hasil Pengukuran (detik) \\
\hline 1 & 904 \\
\hline 2 & 903 \\
\hline 3 & 904 \\
\hline 4 & 902 \\
\hline 5 & 903 \\
\hline 6 & 903 \\
\hline 7 & 904 \\
\hline 8 & 902 \\
\hline 9 & 904 \\
\hline 10 & 904 \\
\hline Rata-Rata & $\mathbf{9 0 3 , 3}$ \\
\hline Koreksi & $\mathbf{3 , 3}$ \\
\hline Error(\%) & $\mathbf{0 , 3 6 \%}$ \\
\hline
\end{tabular}

Medika Teknika : Jurnal Teknik Elektromedik Indonesia, Vol 01 No. 2, April 2020 |63 


\section{Hardono, Supriyadi \\ Modifikasi Autoclave Berbasis Atmega328 (Suhu)}

Dapat dilihat pada Tabel 2 pengukuran yang telah dilakukan menggunakan stopwatch untuk mengetahui hasil timer pada alat, dengan dilakukan pengambilan data sebanyak 10 kali percobaan. Perbedaan waktu yang di-setting dengan alat pembanding, mungkin bisa terjadi karena kesalahan dalam memulai menekan stopwatch secara bersamaan ketika timer pada modul penelitian berjalan sehingga hasil yang didapat berbeda.

\subsection{Pengujian Sterilisasi Peralatan Kesehatan (Alat Bedah)}

Pengujian sterilisasi peralatan kesehatan dilakukan sebanyak 5 kali dengan waktu yang berbeda-berbeda, menggunakan tape autoclave sebagai indikator steril atau tidak steril. Tape autoclave akan menunjukan steril jika berwarna coklat kehitaman, sedangkan jika tidak steril garis coklat kehitaman itu terlihat samar-samar.

Tabel 3. Pengujian Sterilisasi Peralatan Kesehatan (Alat Bedah)

\begin{tabular}{|l|l|l|l|}
\hline No & Timer & Hasil & Gambar \\
\hline 1. & 5 menit & Tidak Steril & \\
\hline 2. & 10 menit & Tidak Steril & \\
\hline 3. & 13 menit & Tidak Steril \\
\hline 5. & 15 menit & Steril \\
\hline
\end{tabular}

Tabel 3 merupakan hasil dari pengujian untuk proses sterilisasi peralatan kesehatan. Proses uji dilakukan dengan cara menempel autoclave tape pada peralatan kesehatan yang akan disterilkan yang sebelumnya telah dibungkus dengan kain. Dari data tersebut didapat hasil bahwa peralatan kesehatan akan steril dengan waktu 15 menit dan 18 menit. Jika waktu kurang dari itu belum bisa dikatakan steril. Suatu peralatan bedah dapat disebut steril dengan ditandai garis coklat kehitaman, dengan mengidentifikasi bahwa elemen pemanas sterilisator bekerja sesuai dengan standar.

\section{KESIMPULAN}

Setelah melakukan proses pembuatan alat, melakukan studi literature, dan telah melakukan beberapa pengukuran dan pengujian alat, dapat disimpulkan bahwa :

a. Alat modifikasi Autoclave berbasis ATMega 328p berfungsi dengan baik, dengan adanya kontrol tekanan dan control valve yang dapat bekerja membuang uap secara 


\author{
Hardono, Supriyadi \\ Modifikasi Autoclave Berbasis Atmega328 (Suhu)
}

otomatis. Dengan suhu standar $121^{\circ} \mathrm{C}$ dengan tekanan 1,1 bar yang ditampilkan dalam bentuk digital.

b. Telah dilakukan pengukuran dengan memiliki error kurang dari 5\%. Dan alat ini telah dilakukan pengujian untuk proses sterilisasi, yaitu dengan cara mensterilkan peralatan bedah minor dan didapat hasil yang baik.

c. Pada pengukuran tekanan senilai $121^{\circ} \mathrm{C}$ dilakukan sebanyak 10 kali, didapat nilai koreksi 0,14 dan eror sebesar $0,115 \%$.

d. Pada hasil pengukuran timer sebanyak $10 \mathrm{kali}$, didapat timer pada alat terlambat 4 detik dari stopwatch, sehingga memiliki nilai akurasi sebesar 4 .

e. Pada hasil pengujian sterilisasi didapat hasil bahwa peralatan kesehatan akan steril dalam waktu sterilisasi selama 15 menit dan 18 menit, namun pada umumnya proses sterilisasi menggunakan waktu selama 15 menit.

\title{
DAFTAR PUSTAKA
}

[1] Z. R. Sopacua, "Sterilisator Basah Menggunakan ATMega8535," 2013.

[2] S. D. Astuti, R. Basalamah, and M. Yasin, "Potensi Pemaparan Light Emitting Diode (LED) Inframerah Untuk Fotoinaktivasi Bakteri Bacillus subtilis," vol. 10, no. 2, pp. 42-52, 2013.

[3] M. Y. Rakhmatullah, I. W. R. Kawitana, and M. T. Akif Rakhmatillah, S.T., "Rancang Bangun Sistem Sterilisasi Alat-alat Kedokteran secara Otomatis," vol. 136, no. 1, pp. $23-$ 42, 2007.

[4] U. Brawijaya and U. Brawijaya, "Instruksi Kerja Pemakaian Autoclave Laboratorium Mikrobiologi dan Imunologi Instruksi Kerja Pemakaian Autoclave Program Kedokteran Hewan," J. Kesehat., vol. 3, pp. 1-3, 2012.

[5] D. F. Hartono, A. Pudji, and M. A. T. . Prastawa, "Incubator Bakteri Bacillus Stearothermophillus berbasis Mikrokontroller untuk tes Mikrobiologi pada Autoclave," vol. 1, no. 2, pp. 1-14, 2016.

[6] N. Vishal Gupta and K. S. Shukshith, "Qualification of Autoclave," Int. J. PharmTech Res., vol. 9, no. 4, pp. 220-226, 2016.

[7] M. M . Fauzi Abdillah, Tribowo Indrato ST , MT , Endro Yulianto , ST, "Modifikasi Autoclave Berbasis Mikrokontroller AT8s51," no. 10. 